\title{
父性意識に関する文献研究
}

—看護・医学領域に視点をあて—

渡部節子 ( 横浜市立大学医学部付属高等看護学校)、臼井雅美 (東邦大学佐倉看護専門学校)、 谷崎 恵 ( 横浜市衛生局医療対策部)

I はじめに

近年、核家族化、共働き夫婦の増加など家 族を取り巻く社会が変化し、家庭における父 親の役割が注目されてきている。

母性看護においても両親学級や夫立ち会い 分婏など父親の関わりが重要視され、それに 関連した研究報告が徐々に成されてきている。

私達は、父親を含姆性看護の充実のた めに、父性研究の現状を把握する必要性を感 じた。そてで、今回は、父性意識を取り扱う 文献内容の特徴を明らかにし、今後の研究に 必要な課題を検討するため、父性意識に関す る19年間の文献を検索し、分析を行った。

\section{II 研究方法}

1973 年から 1991 年までの父性意識に関す る看護・医学領域の文献を“父親・父性・父 ・パパ・父性意識・父性行動・父子”の 7 項 目のキーワードを設定し、その文献の主題・ 副題より検索した。検索方法としては、J O I S ( 1981年〜 1991年)を用いると共に、医 学中央雑誌 ( 1979年〜 1991年) と日本看護関 係文献集（1973年～1978年、1984年～1989年) 最新看護索引（1988～1990年)でマニュアル 検索を行った。

総検出数は 117 件であった。そしてさらに てれらの文献の内容を $\mathrm{K} J$ 法にて分類した。

\section{III結果および考察}

1. 文献の分類とその内容の特徵

K J 法にて分類したその内容に対して、父 性意識が芽生え、目覚めていくプロセスにお いて父性意識に影響を及ぼす要因および父性
意識が及ぼす影響を“父性意識に影響を及ぼ しあう要因”、また父性意識のプロセスを追 及している内容を“父性意識の受容と形成” さらに父性意識や行動の現状を調查した内容 を“父性意識の実態”、どてにも属さない内 容をまと阮てその他”とネーミングした。

さらにてれらを 4 期に分けたライフサイク ル、A 期：出生〜青年期 ( 18歳 )、B期：19 歳〜妻の妊娠以前、 $\mathrm{C}$ 期：妻の妊娠・出産の 時期、 $\mathrm{D}$ 期：育児期に照らし合わせて見た。

\section{(表1)}

文献の内容は、「父性意識に影響を及ぼし あう要因」56件 ( 47.9\%) 、「父性意識の実 熊」37件 $(31.6 \%)$ 、「父性意識の受容と形

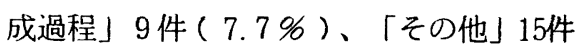
(12.8\%)であった。（図1）

「父性意識に影響を及ぼしあう要因」 「父性意識の実態」の 2 項目で $79.5 \%$ を占め るが、とれは父親ととどもの関係・父親点ど のようにとらえられているか・育児行動など 意識や行動を表出したものであり、研究者が 取り組みやすい結果であると考える。

しかし、全体の中で最も少なかった「その 他」の研究内容涊、父性・父性意識など概念 に関することが主であった。父性における概 念研究が少ないととは、今までの看謢・医学 領域における研究者か報告しているように本 研究であ明らかにされた。

\section{2. 父性意識に影響を及ぼし沾う要因}

「父性意識に影響を及ぼしあう要因」をう イフサイクル各期に照らし合わせてみると、 $\mathrm{A}$ 期17件 (30.4\%)、C 期は17件 (30.4\%)、 D期は22件 ( $39.2 \%$ ) であった。 


\begin{tabular}{|c|c|c|c|c|c|}
\hline 内容 & $\begin{array}{c}\mathrm{A} \text { 期 } \\
\text { (出生一青年 } \\
\text { 期 ( } 18 \text { 歳) }\end{array}$ & $\begin{array}{c}\text { B期 } \\
\text { ( } 19 \text { 歳〜妻の } \\
\text { 妊娠以前) }\end{array}$ & $\begin{array}{c}\mathrm{C} \text { 期 } \\
\text { ( 妻の妊娠 } \\
\text { 出産時期) }\end{array}$ & $\begin{array}{c}\mathrm{D} \text { 期 } \\
\text { (育览期 ) }\end{array}$ & 合 計 \\
\hline $\begin{array}{l}\text { 1.父性意識に } \\
\text { 影響を这し } \\
\text { 合う要因 }\end{array}$ & $\begin{array}{c}17 \\
(30.4)\end{array}$ & & $\left(\begin{array}{c}17 \\
30.4\end{array}\right)$ & $\begin{array}{c}22 \\
(39.2)\end{array}$ & 56 \\
\hline $\begin{array}{l}\text { 2.父性意識の } \\
\text { 受容と形成過 } \\
\text { 程 }\end{array}$ & & $\left(\begin{array}{c}1 \\
11.1\end{array}\right)$ & $\left.\begin{array}{c}8 \\
(88.9\end{array}\right)$ & & 9 \\
\hline $\begin{array}{l}\text { 3.父性意識の } \\
\text { 実態 }\end{array}$ & & $\begin{array}{c}4 \\
(10.8)\end{array}$ & $\left.\begin{array}{c}13 \\
(35.1\end{array}\right)$ & $\begin{array}{c}20 \\
(54.1)\end{array}$ & 37 \\
\hline \multirow[t]{2}{*}{ 4.その他 } & & & $\left(\begin{array}{c}1 \\
6.7\end{array}\right)$ & & \multirow[t]{2}{*}{15} \\
\hline & \multicolumn{4}{|c|}{$14(93.3)$} & \\
\hline
\end{tabular}

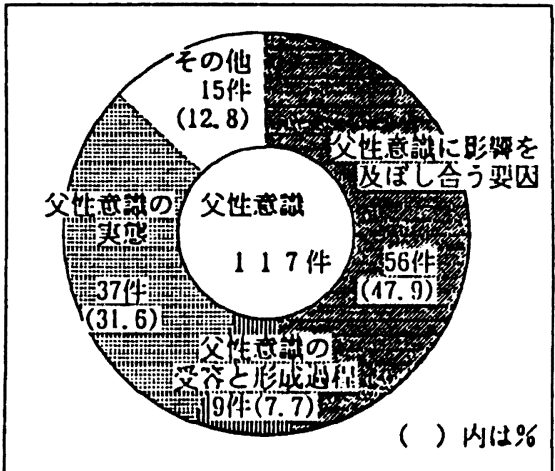

図 1. 父性意識の内容

·A期では子供を主体として父親からの影響 またD期においては父親を主体として子供か らの影響について研究されていた。 $\mathrm{A}$ 期とは 父性が正ディプス期に沶いて「父親への同一 化」として始まり、青年期で「性の同一化」 へと移行していく時期が含まれ、また、ての 時期は家族からの養育を必要とするため、特 に父親からの影響を受けやすい時期と言える。

一方、 $\mathrm{C}$ 期では両親学級や夫立ち会い分婏 が父性意識に及ぼす影響に関する文献が多か った。てれは夫の関心が出産・育児に伴い具
体的なものへと変化したり、主体的に分娩 · 育児に取り組もうとする夫婦加増加し学習へ のニーズが高まる一方、両親学級・夫立ち会 い分婏など学習の場や機会が次第に増加する など現代の社会情勢を示唆している。

$\mathrm{D}$ 期は、児の受容や父親の養育態度などの 研究が成されている。てれは、児の出生が引 き金となり、育児によって父性か急激に発展 し強められた結果と考えられる。

3. 父性意識の受容・形成過程

9 件中 8 件が $\mathrm{C}$ 期で、残り 1 件は $\mathrm{B}$ 期であ った。

従来“父性”之は妻の妊娠・出産によって 芽生えてくるあのとされているため、妻の妊 娠・出産の時期に集中しているのではないか と思われる。さらに母性看護に携わる者とし て妊娠・出産は父性意識を観察しやすいこと あ要因としてあげられる。

\section{4. 父性意識の実態}

B期から研究され始め、C 期は 13 件、 $D$ 期 は20件と $\mathrm{C}$ 期・ D 期に集中していた。内容は 育児行動・養育態度などが多く、てれは子供 が生まれることによって父性意識が父性行動 として表出され、調査しやすいためと思われ 
る。

IV まとめ

今回、父性研究の現状を把握するために、 父性意識に関して看護・医学領域において文 献検索を行なった。

その結果、文献内容は父性意識に影響を及 ぼしあう要因、および父性意識の実態に集中 し、父性の受容・形成過程については少なか った。

さらに内容をライフサイクルから見ると、 妻の妊娠・出産・育児の時期に集中し、19才 から妻の妊娠以前は少ないという特徴が明ら かになった。

そてで、今後“心理学”“社会学”まで検 索の範囲を拡大するとともに、父性意識の受 容·形成過程を出生加ら妻の妊娠以前に焦点 をあて追及していくことが課題となる。 


\section{父性 意識と行動 調 査}

— 妻の妊娠中の意識と行動 —

\section{○ はじめに}

昨今の少産少子の傾向は、社会的にも大き く問題視されるようになってきた。その理由 の一つには、女性にとって妊娠・出産がそれ ほど魅力的なむのと映っていないてとが上げ られている。核家族が多く、地域的サポート あ少ない現在の環境下において、女性か妊娠・ 出産への魅力を取り戻す為には、夫の妊娠・ 出産・育児に対するかかわりは大きく重要視 されることであろう。しかしながら、父性や 育児性の開発にむけての研究教育や社会シス テムはまだまだ未熟な状態であると言えよう。

そとで今回我々はその開発の一助としたく、 まず妻の妊娠中の現状を知る目的で、(1)父親 の身体的状況はどうであったのか、(2)父親と しての意識はいつでろからどのように感じた のか、(3)生活の中での父親としての行動、又 社会の中での父親の動向等、精神的側面之実 際的側宅でのサポートの実態を調查した。

\section{調查方法}

期間と対象：1991年 9 月 11月に聖マリ 了病院で分娩予定の助産婦学生の継続受持妊 婦の夫 31 名 ( 初産婦の夫13名、経産婦の夫 18 名)

方法：妊娠末期の産前家庭訪問の際、受持 妊婦に夫へのアンケート用紙を依頼し、次回 の健診時に回収した。アンケート形式は選択 式と自け記述式との組み合わせで行った。

\section{調查結果と考察}

1. 父親の身体的状況 $\langle$ 表 $1>$

妻の妊娠中、体調を崩した者は31名中 4 名 (12.9\%)、又職場に括いて精神的ストレス
聖マリア学院短期大学

緒方妙子・西 央子・柴田理恵·正本宗子 を感じた者は 7 名 (22.6\%)であり、共に初 産婦の夫に多く、不調の程度は軽度の者がほ とんどで、体調変化の時期は様々であった。

表 1 奼娠期間中の父親の体調変化

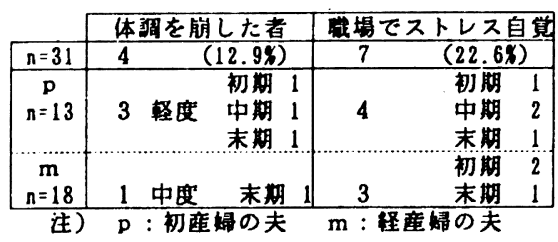

2. 妻の妊娠中の父性意識

1）妊娠を知った時期と反応 妊娠を知った時期は全員妊娠初期であ った。「その時の気持ちはどうでしたか」 では、“うれしい、やった!やっとでき たか”“元気に有ってほしい”等、積極 的肯定的表現の者が24名 (77.4\%)であ った。このうちの経産の 3 名は比較的冷 静に“今度は男の子がほしい”等、具体 的なイメージを述べていた。

又、初産の他の 3 名 (23.1\%)は、 “圥談かと思った”“実感があまりなか った”“複雑な気持ち”之表現し、経産 の他の 4 名は、“うれしいが、前回つら そうだったので心配である”等、やゃ困 惑的表現む見られていた。

2) 妊娠期間中の自己变化の自覚

「妻の妊娠によって自分自身いつ頃よ りどう変わったと思いますか」の問いで、 変化の自覚があった者は18名 (58.1\%) であった。自覚なしの経産の中には、初 めてではないので、あえて意識したてと はなかったと答えた者もあった。変化の 時期は、初産ではまちまちであったが、 経産では初期が多かった。内容は、精神 
的側面では“やさしくなった、いたわり、 思いやり出た、気を遣う”が6名、“妻 の体調を気遣う”が2名、と妻に対して の態度変化の自覚が 8 名で、“あっとし っかりしなければ、責任感の増大”落ち つきが身についた”等自分自身への態度 の自覚が 4 名であった。

又、実際的側面として、“運転、夕バ コへの注意” “家庭中心の生活へ” “買 物や重物持つ”等の行動変化を自覚した 者が 3 多、“給料をふやそう、生活設計” が 2 名、又経産で“上の子と遊ぶように なった”が1名いた。全体的には精神的 側面での変化を多く意識していた。

3）妊娠期間中の父親としての自覚 $\langle$ 表 $2>$

「自分が父親として自覚し、意識して 行動を始めたのはいつ頃ですか」の問い で、自覚のあった者は18名 ( $58.1 \%)$ で あった。自覚時期は、初産では中期に多 く、経産は初期に多かった。行動の内容 では、実際的なサポート行動より、精神 的側面の変化を多く述べていた。

表 2 妊娠期間中の父親としての自覚

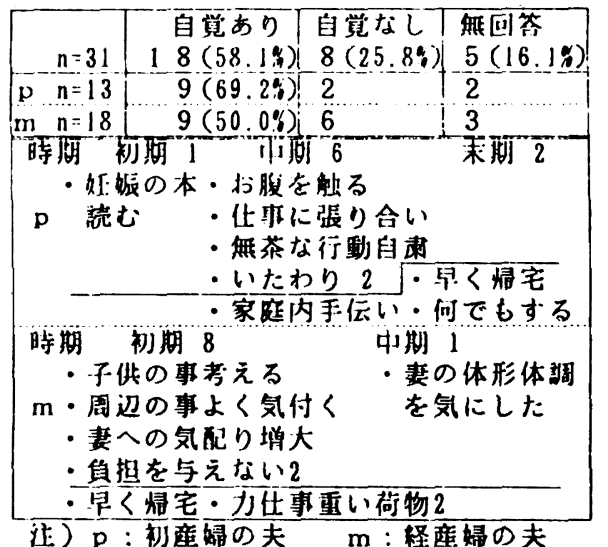

\section{3. 妻への気遣いの内容 $\langle$ 表 $3>$}

初産は身体的側面が多いのに対し、経産は 精神的側面も多くなっていた。

4. 生活の中での父親としての行動
1）胎児への関心行動 $<$ 表 4>

a 育児書等による知識獲得行動は26名 （83.9\%）にみられていた。

b 胎動時腹部触る行動は全員みられて いた。

c 育児用品買い物行動は23名 ( $74.2 \%$ ) とみられていた。

表 3 妊娠期間中の妻への気遣い

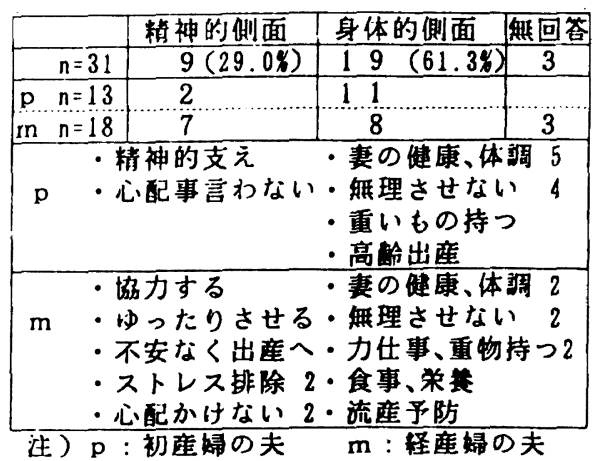

表 4 父親の胎児への関心行動

\begin{tabular}{|c|c|c|}
\hline $\begin{array}{r}\text { 知竓檴得 } \\
n=31 \\
\end{array}$ & $\begin{array}{l}\text { क } \\
26(83.98)\end{array}$ & $\begin{array}{l}\text { なし } \\
5(16.14)\end{array}$ \\
\hline 時期 & 切期 中期 & 不明 \\
\hline$n=13$ & $12(92.3 \%) 3$ & 3 \\
\hline$n=18$ & $14(77.8 \%) 6$ & 5 \\
\hline $\begin{array}{l}\text { 㧍腹を蛽る } \\
\text { 胎児と話し }\end{array}$ & $\begin{array}{l}\text { कり } \\
31(1008)\end{array}$ & $\begin{array}{l}\text { कL } \\
0\end{array}$ \\
\hline $\begin{array}{c}\text { 每复点 } \\
n=31\end{array}$ & $\begin{array}{l}5 y \\
23(74.2 \%)\end{array}$ & $\begin{array}{l}\text { なL } \\
8(25.8 \%)\end{array}$ \\
\hline 時期 & 中期 末期 & 不明なし \\
\hline p $n=13$ & $12(92.38)$ & $i$ \\
\hline m $n=18$ & $11(61.1 \%)^{5}$ & 1 \\
\hline
\end{tabular}

2）妻へのサポート行動〈表 $5>$

a 心配事相談

「妻に心配事を相談された事がありま すか」では、“はい”が14名(45.2\%) であった。初産では相談されたととが 多いのに対し、経産では心配事がなか ったのかその逆であった。

b 異常時の連絡

経産に 2 名のみ連絡不可能の者がいた。 c 家事手伝い 28名 ( 90.3\%) がしていて、初期から 
が多い。

表 5 妊娠期間中の妻へのサポート行動

\begin{tabular}{|c|c|c|c|}
\hline $\begin{array}{c}\text { 心配事相锬 } \\
n=31\end{array}$ & \begin{tabular}{l|l} 
おり & なし \\
$14(45.2 \%)$ & 16( \\
\end{tabular} & & $\begin{array}{c}\text { 無回答 } \\
1 \\
\end{array}$ \\
\hline$p \quad n=13$ & $9(69.28) \quad 4$ & $.88)$ & \\
\hline m $n=18$ & $5(27.8 \%) 12($ & $.78)$ & 1 \\
\hline 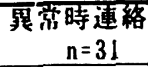 & $\begin{array}{l}\text { कり } \\
29(93.5 \%)\end{array}$ & & $\begin{array}{l}\mathrm{L} \\
(6.5 \%)\end{array}$ \\
\hline p $n=13$ & $13(100 \%)$ & 0 & \\
\hline m $n=18$ & $16(88.98)$ & & $(11.1 \%)$ \\
\hline $\begin{array}{c}\begin{array}{c}\text { 家事手伝い } \\
n=31\end{array} \\
\end{array}$ & $\begin{array}{l}\text { कण } \\
28(90.3 \%)\end{array}$ & & $\begin{array}{c}\text { なL } \\
3\end{array}$ \\
\hline 時期 & 初期 & 口期 & なし \\
\hline p $n=13$ & $13(100.8)$ & 3 & \\
\hline m $n=18$ & $15(83.3 \%)$ & 5 & 3 \\
\hline
\end{tabular}

5. 社会の中での父親としての行動 $<$ 表 6>

1）経済意識

「妻が出産する事に対し経済的な不安が ありますか」では、“はい”が 7 名(22.6 \%)で、経産は 3 人に 1 人の割合で不安 を示していた。

2）職場近所での交際

「生まれてくる赤ちゃんの事で、近所の 人や眓場の人と話をしたてとがあります

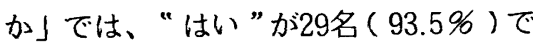
あった。

3）妊娠分婏への参加希望

a 妊婦健診付添い希望は35.5\%であっ た。

b 母親学級参加希望は $16.1 \%$ であった。

c 分婏時付添い希望は61.3\%であった。
表 6 社会の中での父親としての行動

\begin{tabular}{|c|c|c|}
\hline 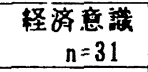 & $\begin{array}{l}\text { 不安なし } \\
24(77.4 \%)\end{array}$ & $\begin{array}{l}\text { 不安あり } \\
7(22.6 \%) \\
\end{array}$ \\
\hline $\begin{array}{ll}\text { p } & n=13 \\
\text { m } & n=18\end{array}$ & $\begin{array}{l}12(92.3 \%) \\
12(66.78)\end{array}$ & $\begin{array}{l}1(7.7 \%) \\
6(33.38)\end{array}$ \\
\hline $\begin{array}{l}\text { 磪場近所で } \\
\text { 交際 } n=31\end{array}$ & $\begin{array}{l}\text { कり } \\
29(93.5 \%)\end{array}$ & \begin{tabular}{|l|}
$L$ \\
$2(6.5 \%)$ \\
\end{tabular} \\
\hline 時期 & 初期 中期 & 末期 不明师し \\
\hline p $n=13$ & $13(100 . \%) 5$ & 6 \\
\hline m $n=18$ & $16(88.98) 7$ & $2: 2$ \\
\hline $\begin{array}{l}\text { 健琴付婇 } \\
\text { 希望 } n=31\end{array}$ & $\begin{array}{l}\text { あり } \\
11(35.58)\end{array}$ & $\begin{array}{l}\text { なL } \\
20(64.5 \%)\end{array}$ \\
\hline p $n=13$ & $5(38.5 \%)$ & $8(61.5 \%)$ \\
\hline$n=18$ & $6(33.4 \%)$ & $12(66.74)$ \\
\hline $\begin{array}{l}\text { 每顛学級 } \\
\text { 望 } n=31\end{array}$ & $\begin{array}{l}\text { あり } \\
5(16.14) \\
\end{array}$ & $\begin{array}{l}\text { なL } \\
26(83.98)\end{array}$ \\
\hline p $n=13$ & $2(15.4 \%)$ & $11(84.68)$ \\
\hline m $n=18$ & $3(16.7 \%)$ & $15(83.3 \%)$ \\
\hline $\begin{array}{l}\text { 可婏時付添 } \\
\text { 希望 } n=31\end{array}$ & $\begin{array}{l}\text { कり 妻望 } \\
19(61.3 \%)\end{array}$ & \begin{tabular}{|c|c|} 
ठईख & +2 \\
1 & $1(35.5 \%)$ \\
\end{tabular} \\
\hline p $n=13$ & $10(76.9 \%)$ & $3(23.18)$ \\
\hline $\mathrm{m} \quad \mathrm{n}=18$ & $9(50.0 \%)$ & $8(44.4 \%)$ \\
\hline
\end{tabular}

○結語

1. 妊娠期間中、父親の体調不良は $1 \sim 2$ 割 の者に見られ、経度で、時期は様々であっ た。

2. 妊娠期間中、父親としての意識は 6 割の 者に見られ、初産の父は中期に、経産の父 は初期から変化を自覚し、共に精神的サポ 一トへの変化を自覚しているのが多かった。

3. 妻への気遣いでは、初産の父は身体的側 面が多く、経産では精神的面と平均してい た。

4. 胎児への関心行動は非常に高かったが、 経産の父では初産に比べやや下がっていた。

5. 生活の中での妻への実際的サポートであ る家事手伝いはよくなされていた。

6. 社会的父親行動としての、職場・近所で の交際は多かった。妊娠中の参加希望はま だ少なく、分婏付添希望は初産の父に多か った。 
周産期における母性意識の発達過程と

$$
\text { マタニティブルーとの関連性 }
$$

——産裖期における調查——

宮中文子 - 松岡知子・諸岡豊子 ( 京都府立医科大学附属看護専門学校)、脇田満里子 ( 藍野学院 短期大学 )、入澤みち子 (高槻赤十字病院)、渡辺数江 (宇部看護専門学校)、川中洋子 (大阪 府医師会看護専門学校)、長尾早枝子 (長尾助産院)、新道幸恵 (神戸大学医学部附属病院)

1 はじめに

母性意識は、妊娠の受容・分婏体験・母親 役割獲得という周産期の過程において、子供 との関わりの中で発達し、強められていくと されている。マタニティブルーは、産裖期に 一過性におてる徵候で疾患ではないとされて おり、周産期の発達危機の徴候ではないかと 考えられる。そてで、周産期における母性意 識の発達過程とマタニティブルーについて調 査し、その関連について分析した。

\section{II 研究方法}

1) 対象: 平成 3 年 7 月 平成 4 年 3 月に 京都府、大阪府、山口県の計 5 病院で、 出産した妊娠・分娩が正常に経過した褯 婦270名、ただし、精神病の既往の人は 除外した。

2）方法：産裖 4 日に自記式質問紙調查を 行った。

3）質問項目：周産期の各期の母性意識に 関する項目は、大日向による母性意識の 調查研究や新道らを参考とし、妊娠の受 容の有無など 6 項目を妊娠期の母性意識 分婏の満足度など 8 項目を分娩期の母性 意識とした。産褯早期の母性意識は対児 感情など11項目とした。マタニティブル 一の測定尺度は、高橋らの変法による Zung の自己評価式抑䄷尺度（S D S ) 20項目と、産後に出現率の高い自覚精神 身体症状 ( 自覚症状) の 5 項目とした。

4）用語の定義
母性意識：母親であるととの妊娠・分 婏・育児への態度や価值観である。 母性意識の発達：母性意識は、発達する むのであり、その発達過程とは、母性意 識の肯定的な変容の過程とした。

なお、母性とは、Deutchのいう「社 会学的、生理学的、感情的な統一体とし ての母の子に対する関係を示すすのであ る」ことを踏まえ、母性意識はその一側 面とした。

5）データの分析 : 有効回答の得られた 270 人 ( $100 \%)$ を対象とした。母性意識 の項目は、肯定的な回答に 4 点、どちら かというと肯定的な回答に 3 点、よ゙ちら かというと否定的な回答に 2 点、否定的 な回答に 1 点を配点した。各期の母性意 識の総合得点の平均値で 2 群に分類し、 「高得点群」、「低得点群」とした。S D S、自覚症状の得点は原法に従って各 項目の回答に、いいえ 1 点、ときどき 2 点、かなり 3 点、いつも 4 点を配点した。 本研究では、S D S 総合得点の得点分布 を考慮し、平均値+1 $\sigma$ (31点)を判別 值とし、「抑榔群」、「非抑榔群」に分 類した。また、自覚症状得点も同様に得 点分布を考慮し平均値 $+1 \sigma$ ( 9 点)で 2 群とし、「抑節群」、「非抑榔群」に 分類した。そのうえで、各期の母性意識 (高得点群・低得点群) と、S D S 、自

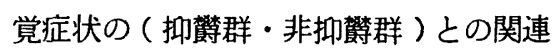
をカイ二乗検定を用いて検討した。 


\section{1 結果と考察}

1. 周産期における母性意識

対象者属性は表 1 亿示した通りであり、年 齢、初経別、家族構成は一般の傾向之同様で あった。
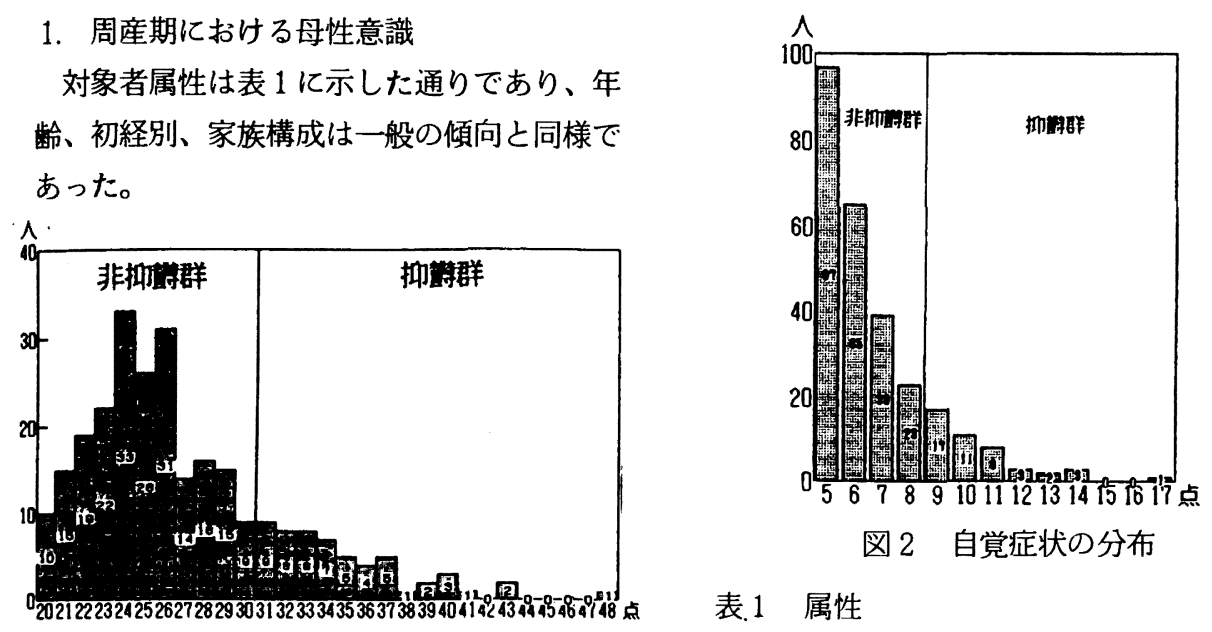

図 1 S D S の分布

図 3 自己評価式抑榔尺度（ＳD S ) の項目別抑㮾程度

\begin{tabular}{|c|c|c|c|c|}
\hline 年点 & 平均 & $28.6(\mathrm{SD}=3.9)$ 成 & & \\
\hline $\begin{array}{l}\text { 家族㨽成 } \\
\text { 扮怪別 }\end{array}$ & $\begin{array}{l}\text { 核家族 } \\
\text { 初産始 }\end{array}$ & $\begin{array}{l}224 \text { 人 }(83.0 \%) \\
134 \text { 人 }(58.0 \%)\end{array}$ & 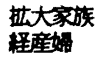 & $\begin{array}{l}46 人(17.0 \%) \\
97 人(42.0 \%)\end{array}$ \\
\hline 准策 & あり & 64人 (23.7\%) & なし & $206 人(76.3 \%)$ \\
\hline 里愲り分婏 & する & $159 人(59.6 \%)$ & しない & 108 人 $(40.4 \%)$ \\
\hline 夫の年筑 & 平均 & $31.3(S D=4.4)$ 些 & & \\
\hline
\end{tabular}

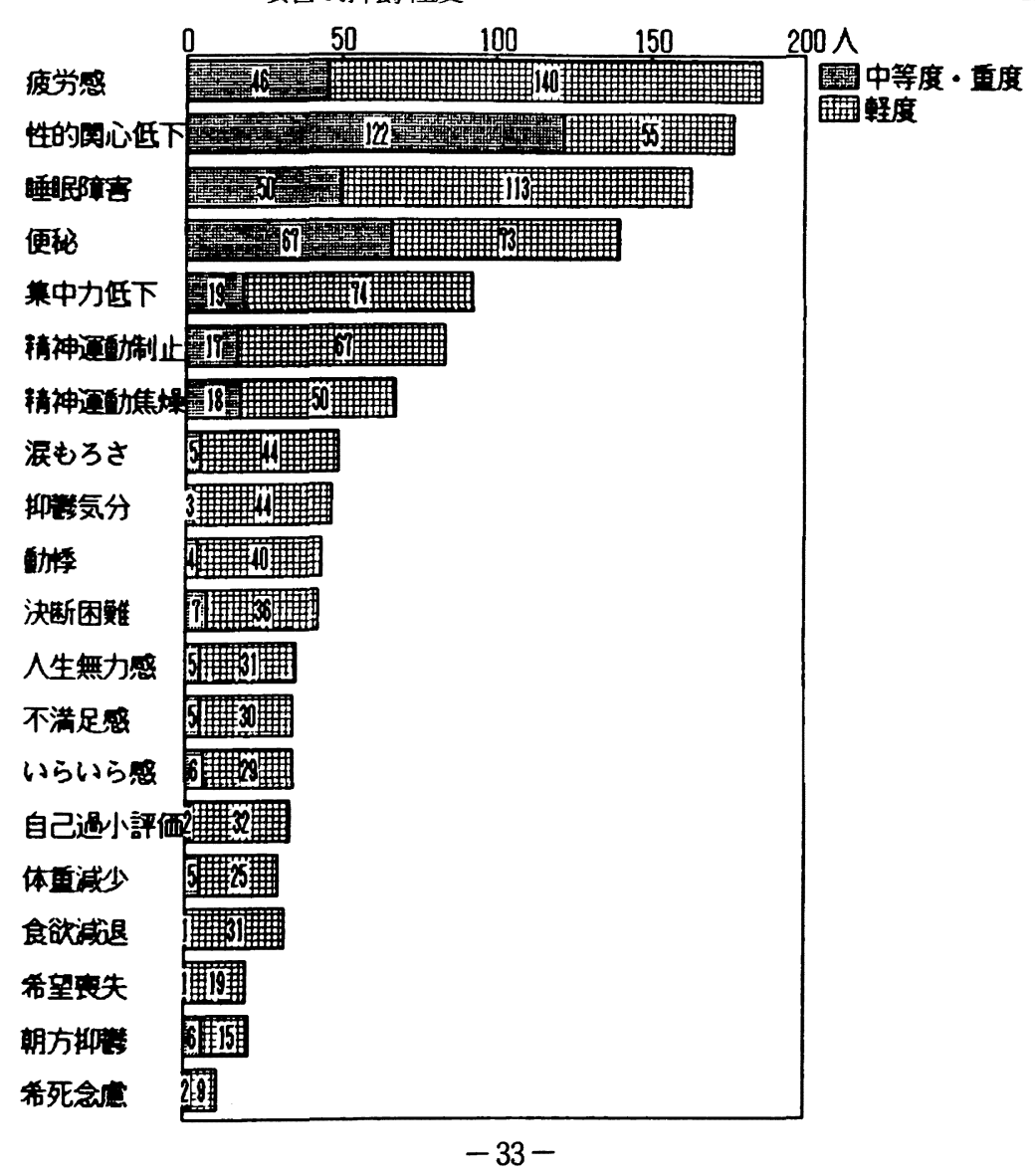


2. 褯婦の抑爵傾向について

1）S D S の抑榔傾向

S D S の軽度以上の抑節之回答した者 の人数は産裖期特有の身体症状が多く認 められ、高橋らの報告之同様の傾向であ った。S D S 得点は、20点〜48点で、平 均 $26.95(\mathrm{SD}=4.9)$ 点であり、高橋らの 裖婦の平均値 $26.35(\mathrm{SD}=5.3)$ 点亡ほぼ 一致した。高橋らのマタニティブルーの 判別値の36点以上を示す者は19人( 7.1 \%)であった。ての19人はマタニティブル 一であった之可能性があるが、高橋らの 報告では $6.5 \%$ であり、これに近い結果 であった。(図3）

2）自覚症状の抑辳傾向について

自覚症状の軽度以上の抑嘼と回答した 者の人数は図 4 に示す通りで、子どあに 対する憂慮、不安感についての回答が多 く見られた。自覚症状得点は 5 点 17点 で、平均值は $6.71(\mathrm{SD}=2.0)$ 点であり、 高橋らの6.53( $\mathrm{SD}=1.1$ ) 点とほぼ同様 の結果であった。(図 4 )

3. 母性意識と抑㮾傾向之の関連

各期の母性意識の高得点群 - 低得点群之、 S D S、自覚症状の抑根群 · 非抑䍚群之の関 連を検討した。（表２）

1）妊娠期の母性意識との関連

S D S の非抑畴群との関連では、妊娠 期の母性意識の高得点群が多く有意の関 連が認められた。項目別では、「妊娠し て嬉しい」、「妊娠中の生活は快適」と 答えた者では、S D S の非抑爰群が多く、
「出産が近づくのは不安」と答えた者で は、S D S の抑欎群が多く、それぞれ有 意の関連か認められた。また、自覚症状 についても2 項目に有意の関連が認めら れた。

2）分娩期の母性意識との関連

S D S の非抑根群との関連では、分婏 期の母性意識の高得点群が多く、項目別 では「分婏満足」、「女に生まれ幸せ」 と答えた者では、S D S の非抑欝群が多 く、「分娩はうまくできなかった」、「赤 ちゃんのてよより自分の事しか考えられ なかった」、「取り乱して自分を失いそ うだった」、「苦痛は耐えられなかった」 と答えた者では、S D S の抑榔群が多く、 それぞれ有意の関連が認められた。また、 自覚症状についてむ、3 項目について有 意の関連が認められた。

3）産袮期の母性意識との関連

S D S の非抑檾群との関連では、産褯 期の母性意識の高得点群が多く、項目別 では「抱くとフイットする」と答えた者 では、S D S の非抑榔群が多く、「泣く といらいらする」と答えた者では、SDS の抑稂群が多く有意の関連が認められた。 また、自覚症状については、4項目につ いて有意の関連か認められた。

てれらのととから、産裖期の抑㮐は、妊娠 期、分娩期、産裖期それぞれの時期での母性 意識の発達変容が影響しているととが示唆さ

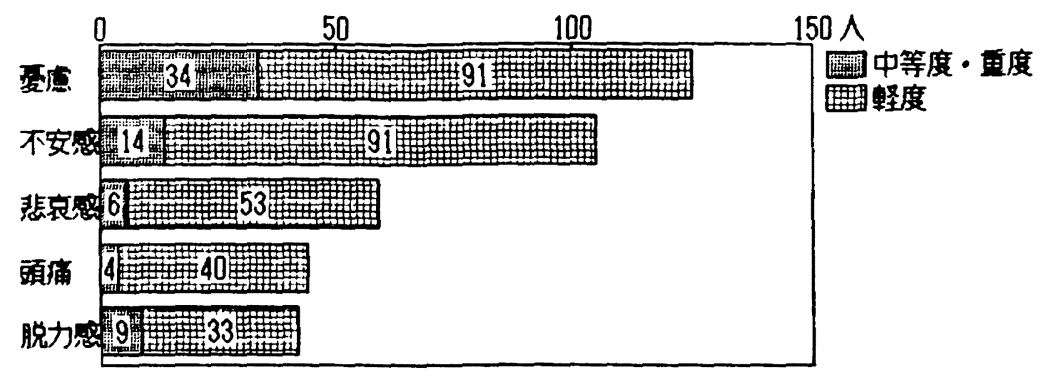

図 4 自覚症状の項目別抑欝程度 
れた。和田らは、分婏体験の想起は産裖期の

肯定的感情につながるとしており、妊娠期で は妊娠が受容でき、分娩期では分娩が満足し た体験であり、産褯期では対児感情を育むな
ど、周産期での母性意識の発達を促すととに より、抑榔の軽減となり、マタニティブルー

の発症を少なくすると思われ、今後、プロス ペクティブな調査が必要であると考えた。

表 2 周産期の母性発達項目とS D S 、自覚症状との関連

\begin{tabular}{|c|c|c|c|c|c|c|}
\hline \multirow{2}{*}{\multicolumn{3}{|c|}{ 項 目 }} & \multicolumn{2}{|c|}{ SDS } & \multicolumn{2}{|c|}{ 自哯庭状 } \\
\hline & & & 非抑场群 & 抑地样 & 非抑簐群 & 抑坷群 \\
\hline \multicolumn{2}{|c|}{ 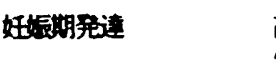 } & $\begin{array}{l}\text { 识得点群 } \\
\text { 低待点群 }\end{array}$ & $\begin{array}{r}121(65.1) \\
35(44.3)\end{array}$ & $\begin{array}{l}65(34.9) \\
44(55.7) * *\end{array}$ & $\begin{array}{r}163(86.2) \\
61(77.2)\end{array}$ & $\begin{array}{l}26(13.8) \\
18(22.8)\end{array}$ \\
\hline \multirow{3}{*}{$\begin{array}{l}\text { 姡 } \\
\text { 張 } \\
\text { 期 } \\
\text { 無 } \\
\text { 䢖 } \\
\text { 項 } \\
\text { 目 }\end{array}$} & 奸娠して媓しい & $\begin{array}{l}\text { はい } \\
\text { いいえ }\end{array}$ & $\begin{array}{r}141(62.7) \\
15(36.6)\end{array}$ & $\begin{array}{l}84(37.3) \\
26(63.4) * *\end{array}$ & $\begin{array}{r}194(85.5) \\
30(71.4)\end{array}$ & $\begin{array}{l}33(14.5) \\
12(28.6) *\end{array}$ \\
\hline & 娃姬中生活快通 & $\begin{array}{l}\text { はい } \\
\text { いいえ }\end{array}$ & $\begin{array}{l}76(68.5) \\
80(51.6)\end{array}$ & $\begin{array}{l}35(31.5) \\
75(48.4) * *\end{array}$ & $\begin{array}{l}102(90.3) \\
122(78.2)\end{array}$ & $\begin{array}{l}11(9.7) \\
34(21.8) *\end{array}$ \\
\hline & $\begin{array}{l}\text { 出産が近つくの } \\
\text { は不安 }\end{array}$ & $\begin{array}{l}\text { はい } \\
\text { いいえ }\end{array}$ & $\begin{array}{r}10(29.4) \\
146(62.9)\end{array}$ & $\begin{array}{l}24(70.6) \\
86(37.1) * *\end{array}$ & $\begin{array}{r}25(73.5) \\
199(84.7)\end{array}$ & $\begin{array}{r}9(26.5) \\
36(15.3)\end{array}$ \\
\hline \multicolumn{2}{|c|}{ 分娚期発䢖 } & $\begin{array}{l}\text { 影得点群 } \\
\text { 低得点群 }\end{array}$ & $\begin{array}{r}106(73.1) \\
47(41.6)\end{array}$ & $\begin{array}{l}39(26.9) \\
66(58.4) * *\end{array}$ & $\begin{array}{r}130(88.4) \\
88(77.2)\end{array}$ & $\begin{array}{l}17(11.6) \\
26(22.8) *\end{array}$ \\
\hline \multirow{6}{*}{ 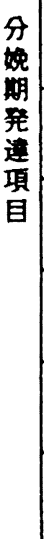 } & $\begin{array}{l}\text { 分娩を終えて } \\
\text { 满足している }\end{array}$ & $\begin{array}{l}\text { はい } \\
\text { いいえ }\end{array}$ & $\begin{array}{r}147(61.3) \\
9(34.6)\end{array}$ & $\begin{array}{l}93(38.7) \\
17(65.4) *\end{array}$ & $\begin{array}{r}207(85.2) \\
17(65.4)\end{array}$ & $\begin{array}{l}36(14.8) \\
9(34.6) * *\end{array}$ \\
\hline & $\begin{array}{l}\text { 分姢はうまく } \\
\text { できなかった }\end{array}$ & $\begin{array}{l}\text { はい } \\
\text { いいえ }\end{array}$ & $\begin{array}{l}82(50.6) \\
74(71.8)\end{array}$ & $\begin{array}{l}80(49.4) \\
29(28.2) * *\end{array}$ & $\begin{array}{r}130(78.8) \\
93(90.3) \\
\end{array}$ & $\begin{array}{l}35(21.2) \\
10(9.7) *\end{array}$ \\
\hline & $\begin{array}{l}\text { 女に生まれ幸せ } \\
\text { たと思った }\end{array}$ & $\begin{array}{l}\text { はい } \\
\text { いいえ }\end{array}$ & $\begin{array}{l}81(69.8) \\
75(50.0)\end{array}$ & $\begin{array}{l}35(30.2) \\
75(50.0) \neq *\end{array}$ & $\begin{array}{l}102(85.7) \\
122(81.3)\end{array}$ & $\begin{array}{l}17(14.3) \\
28(18.7)\end{array}$ \\
\hline & $\begin{array}{l}\text { 児より自分の事しか } \\
\text { 考えられなかった }\end{array}$ & $\begin{array}{l}\text { はい } \\
\text { いいえ }\end{array}$ & $\begin{array}{l}65(50.0) \\
91(67.4)\end{array}$ & $\begin{array}{l}65(50.0) \\
44(32.6) * *\end{array}$ & $\begin{array}{l}108(81.8) \\
116(85.3)\end{array}$ & $\begin{array}{l}24(18.2) \\
20(14.7)\end{array}$ \\
\hline & $\begin{array}{l}\text { 取り乱して自分を } \\
\text { 失いモうたった }\end{array}$ & $\begin{array}{l}\text { はい } \\
\text { いいえ }\end{array}$ & $\begin{array}{l}83(51.6) \\
73(70.2)\end{array}$ & $\begin{array}{l}78(48.4) \\
31(29.8) * *\end{array}$ & $\begin{array}{r}130(80.2) \\
94(88.7)\end{array}$ & $\begin{array}{l}32(19.8) \\
12(11.3)\end{array}$ \\
\hline & $\begin{array}{l}\text { 苦触は耐えられな } \\
\text { かった }\end{array}$ & $\begin{array}{l}\text { はい } \\
\text { いいえ }\end{array}$ & $\begin{array}{r}111(53.6) \\
45(77.6)\end{array}$ & $\begin{array}{l}96(46.4) \\
13(22.4) * *\end{array}$ & $\begin{array}{r}169(80.9) \\
55(93.2)\end{array}$ & $\begin{array}{l}40(19.1) \\
4(6.8)\end{array}$ \\
\hline \multicolumn{2}{|c|}{ 母子圆係 } & $\begin{array}{l}\text { 誨得点群 } \\
\text { 低得点群 }\end{array}$ & $\begin{array}{r}126(63.6) \\
23(38.3)\end{array}$ & $\begin{array}{l}72(36.4) \\
37(61.7) * *\end{array}$ & $\begin{array}{r}178(89.0) \\
39(63.9)\end{array}$ & $\begin{array}{l}22(11.0) \\
22(36.1) * *\end{array}$ \\
\hline \multirow{5}{*}{$\begin{array}{l}\text { 母 } \\
\text { 子 } \\
\text { 阅 } \\
\text { 係 } \\
\text { 面 } \\
\text { 目 }\end{array}$} & $\begin{array}{l}\text { 泣くと } \\
\text { いらいらする }\end{array}$ & $\begin{array}{l}\text { はい } \\
\text { いいえ }\end{array}$ & $\begin{array}{r}10(27.0) \\
142(63.4)\end{array}$ & $\begin{array}{l}27(73.0) \\
82(36.6) \text { ** }\end{array}$ & $\begin{array}{r}26(70.3) \\
193(85.0)\end{array}$ & $\begin{array}{l}11(29.7) \\
34(15.0) *\end{array}$ \\
\hline & 抱くのか恐い & $\begin{array}{l}\text { はい } \\
\text { いいえ }\end{array}$ & $\begin{array}{r}23(46.9) \\
129(60.8)\end{array}$ & $\begin{array}{l}26(53.1) \\
83(39.2)\end{array}$ & $\begin{array}{r}31(62.0) \\
188(87.9)\end{array}$ & $\begin{array}{l}19(38.0) \\
26(12.1) * *\end{array}$ \\
\hline & おやすと反応する & $\begin{array}{l}\text { はい } \\
\text { いいえ }\end{array}$ & $\begin{array}{l}74(63.2) \\
81(55.5)\end{array}$ & $\begin{array}{l}43(36.8) \\
65(44.5)\end{array}$ & $\begin{array}{l}106(89.8) \\
116(78.4)\end{array}$ & $\begin{array}{l}12(10.2) \\
32(21.6) *\end{array}$ \\
\hline & $\begin{array}{l}\text { 一楮にいると } \\
\text { 果しい }\end{array}$ & $\begin{array}{l}\text { はい } \\
\text { いいえ }\end{array}$ & $\begin{array}{r}143(60.0) \\
12(48.0)\end{array}$ & $\begin{array}{l}95(40.0) \\
13(52.0)\end{array}$ & $\begin{array}{r}207(85.9) \\
15(60.0)\end{array}$ & $\begin{array}{l}34(14.1) \\
10(40.0) * *\end{array}$ \\
\hline & $\begin{array}{l}\text { 抱くと } \\
\text { フィットする }\end{array}$ & $\begin{array}{l}\text { はい } \\
\text { いいえ }\end{array}$ & $\begin{array}{r}127(66.1) \\
28(39.4)\end{array}$ & $\begin{array}{l}65(33.9) \\
43(60.6) * *\end{array}$ & $\begin{array}{r}166(85.1) \\
56(78.9)\end{array}$ & $\begin{array}{l}29(14.9) \\
15(21.1)\end{array}$ \\
\hline
\end{tabular}


神奈川県立衛生短期大学

$\begin{array}{rrr}\text { 大賀 } & \text { 明子 } & \text { 皆川恵美子 } \\ \text { ○山口 } & \text { 由子 } & \text { 藤田八千代 }\end{array}$

$37.1 、 40.0$ 、39.1であり、特性不安は39.4、 $39.7 、 39.9$ であった。各時期の状態不安得点 と特性不安得点の相関係数は $0.583 \sim 0.742$ で あり、状態不安得点どうしの相関係数は 0.563 〜 0.590、また特性不安得点どうしの相関係数 は0.826〜0.881であり、いずれも高い相関が 見られた。得点分布は各時期とも正規分布を 示していた。3 回連続で調查協力が得られた 203名について、その状態不安得点をそれぞ れ、各時期の平均得点土 I S Dを基準として 不安得点が低かった群、中等だった群、高か った群の 3 群に分けたとてろ、表 1 のような 分類ができた。さらに綐断的な変化を追って いくと次のような結果が得られた。すなわち、 入院中に不安得点が低かった群の25名では、 図 1 のように退院 1 週後に低い群になったも のは 9 名でとの分婏 1 力月後の変化は低い群 のままだったもの 7 名、中等になったもの 2 名で、高くなったものはいなかった。退院 1 週後に低い群から中等になったものは14名で、 ての分婏 1 力月後は低い群 5 名、中等群 8 名、 高い群 1 名であった。低い群から退院 1 週後 に高い群になったものは 2 名で、ての 2 名は いずれむ中等になっていた。同様に入院中の 不安得点の分類ごとに縦断的な変化を追って いくとそれぞれ図 2、3のような結果が得ら れた。入院中に中等度の不安状態にあっても 退院 1 週後に低い群へ移行すると 1 力月後に 高くなる群は見られず、反対に 1 週後に高い 群へ移行すると 1 力月後に低くなる群は見ら れなかった。入院中に不安状態が高かった群 に扔いては退院 1 週後に低くなるものは少な 
表 1 状態不安得点の分類

\begin{tabular}{|c|c|c|c|c|}
\hline & 低 い群 & 中 等 群 & 高 い群 & 合 \\
\hline S T A I 得点 (状態不安) & $20 \sim 26$ & $27 \sim 46$ & $47 \sim 71$ & \multirow[b]{2}{*}{$\begin{array}{l}203 \text { 名 } \\
(100 \%)\end{array}$} \\
\hline 入 院 中 & $\begin{array}{c}25 \text { 名 } \\
(12.3 \%)\end{array}$ & ( 150 名 $)$ & $\begin{array}{c}28 \text { 名 } \\
(13.8 \%)\end{array}$ & \\
\hline S T A I 得点 (状態不安) & $21 \sim 30$ & $31 \sim 48$ & $49 \sim 78$ & \multirow[b]{2}{*}{$\begin{array}{l}203 \text { 名 } \\
(100 \%)\end{array}$} \\
\hline 退院 1 週後 & $\begin{array}{c}26 \text { 名 } \\
(12.8 \%)\end{array}$ & $\begin{array}{l}136 \text { 名 } \\
(67.0 \%)\end{array}$ & $\begin{array}{c}41 \text { 名 } \\
(20.2 \%)\end{array}$ & \\
\hline S T A I 得点 (状態不安) & $20 \sim 28$ & $29 \sim 47$ & $48 \sim 73$ & \multirow[b]{2}{*}{$\begin{array}{l}203 \text { 名 } \\
(100 \%)\end{array}$} \\
\hline 分娩 1 力月後 & $\begin{array}{c}25 \text { 名 } \\
(12.3 \%)\end{array}$ & $\begin{array}{l}145 \text { 名 } \\
(71.4 \%)\end{array}$ & $\begin{array}{c}33 \text { 名 } \\
(16.3 \%)\end{array}$ & \\
\hline
\end{tabular}

入院中 退院 1 週後 分婏 1 力月後

低 25

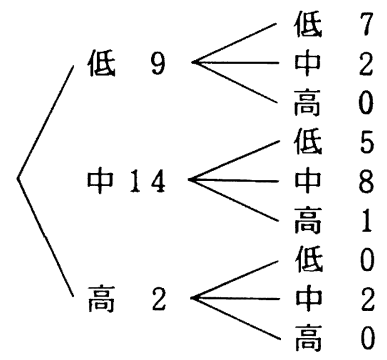

図 1 不安得点群の縦断的変化 (低い群)

入院中 退院 1 週後 分娩 1 力月後

中 150
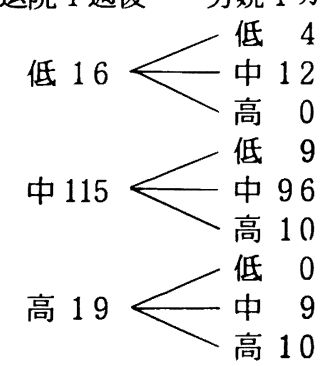

図 2 不安得点群の縦断的変化 (中等群)

く、よ゙ちらかといえば 1 週後、1 1 月後とも 高い群のまま経過する傾向があった。入院中 から低く経過する群と高く経過する群とでそ の裖婦の不安になりやすい性格傾向である特 性不安を見たとてろ、明らかに特性不安得点 も高いことが認められた。また、それぞれに ついて、その属性を見たとてろ、高く経過す
入院中 退院 1 週後 分娩 1 力月後

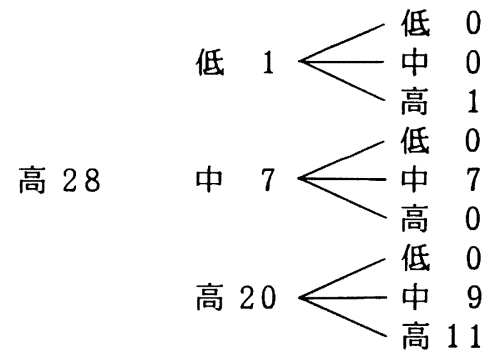

図 3 不安得点群の縦断的変化 (高い群)

る群では初産婦の割合が多い傾向が認められ
た。

考察: 祳婦の不安について、その時の不安状 態を表わす状態不安の変化を追跡していった ところ、入院中の不安得点が低い群では退院 後に高くなっていく傾向は見られず、反対に 入院中の不安得点が高い群では退院後も高い まま経過しやすい傾向があるととがわかった。 また、入院中の不安得点の約 $74 \%$ を占めてい た中等度の不安得点のものは、退院 1 週後に その不安がどう変化するかによって、1 カ月 後の不安得点が左右される傾向があった。と れらの不安得点は褯婦の性格傾向を示す特性 不安得点との関連が強いが、それは特性不安 と状態不安が高い相関を持つととから考えれ 
ば当然とも言える。しかし、入院中の不安傾 向に大きな特徽が見られなくても退院して 1 週後位の時期によ゙のような状態で過でしてい るかがその後の不安に大きく影響していた。 特に不安得点が高功た群浮初産婦が多かっ たという今回の結果や、育児経験の有無や児 の出生順位などが入院中や退院 1 週後の状態 不安と有意な関連を持つというこれまでに報 告してきた属性との関連性から、新生児を迎 える新しい状況に裖婦がよりスムーズに適応 できるように援助していく入院中の看護援助 の重要性がさらに明らかになったと言える。 今回の調查からは、おおまかな傾向を知るて とができたが、統計的に有意であるというに は対象数が充分だとは言え方、現在す継続調 查中である結果を含め今後さらに明らかにし ていきたいと考えている。 
母性性に関する研究 第 5 報

解説文献の動向

神奈川県立衛生短期大学

皆川恵美子 大賀 明子

I はじめに

母性看護におりる母性性伸長の援助は、時 代を越えて母性看護の重要な要素の一つであ ると考える。この伸長すべき母性性について は、“母性意識”“母性行動”など様々に表 現されその概念む不明確なままとなっている。 我々は、乙れら様々に表現されている広い範 囲の概念を母性性とよび、その解釈の動向を 探る目的として 80 種にわたる看護関係誌をキ ーワード（表1）によって検索し、422文献 を得た。その期間は対象誌それぞれの創刊号 から1988年12月までで、53年間に及んだ。 そ心結果として、422文献の概観を1 報に研 究・抄録 256 文献を内容別に 2 から 4 報にそ れぞれ報告してきた。

表 1 文献検索のキーワード

\begin{tabular}{|c|c|}
\hline 「母性性」 & 「母子の絆」 \\
\hline 「母性観」 & 「親子の絆」 \\
\hline 「母性愛」 & 「母性の確立」 \\
\hline 「母性意識」 & 「母親になる過程」 \\
\hline 「母性行動」 & 「母親行動」 \\
\hline 「母性役割」 & 「母子接触」 \\
\hline $\begin{array}{l}\text { 「子関係」 } \\
\text { 「母子相互作用」 }\end{array}$ & 「母性の成熟過程」 \\
\hline
\end{tabular}

今回は、第 5 報として解説 122 文献に分類 されたすのについて分析を行なった。解説と して取上げた文献は、研究・抄録ではなく、 報告、シンポジゥム、講演、その他にも含ま れないものを特に解説として分類した。

1 研究結果
1. 分類別割合 (図 1 ) およびキーワード別 割合 (図2 )について

解説文献は全体の 28.9\%(122 文献以下（） は文献数 )で、最む多い抄録に次いでいた。 キーワード別割合をみると「母子関係」が 23.0\% ( 28 ) と最も多く、次いで「母子相互 作用」 $13.9 \%$ ( 17 )、「母性愛」9.8\%(12)、 「母性意識」 $4.9 \%(6) 、 「 母 子 の$ 絆」 $4.1 \%$ (5)「母性役割」3.3\%(4)の順であった。「母 子の絆」と「親子の絆」の二つのキーワード

\section{図1 分類別割合}

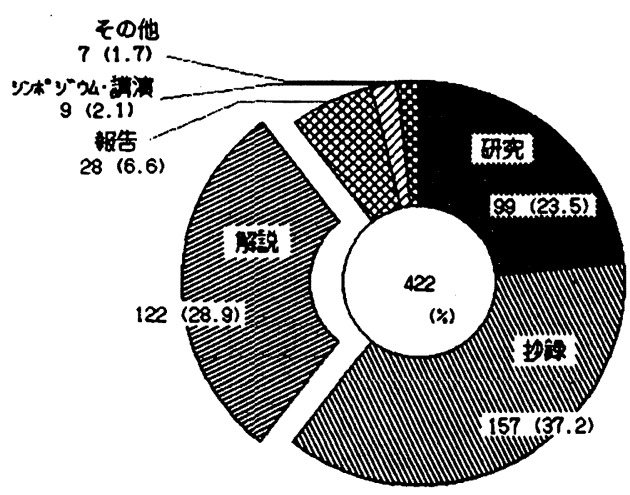

図2 キーワード別割合

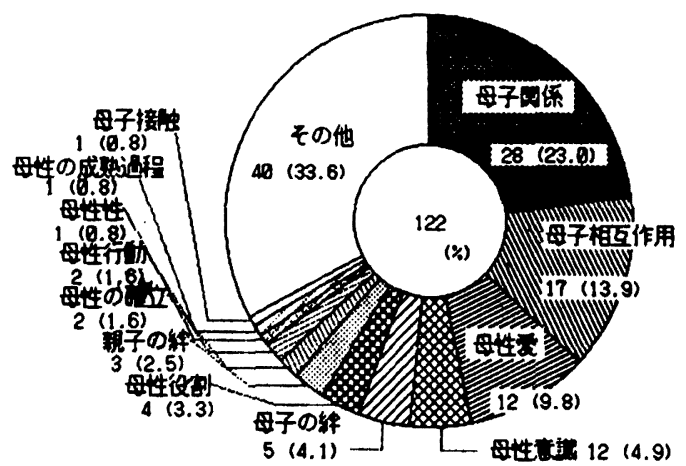


を“絆”としてあわせると6.6\%(8)となり、 「母性意識」なり高い割合となっている。 検索時には、内容がキーワードに含まれる と思われたものも取上げたが、解説はそれに 該当するものがめだったために、(「その他」 32.8\%(40))「その他」に含まれた標題を みると“母”に関するものが56.1\%(23)“母 と子”に関するものが24.4\%(10)であった。 それぞれの標題を見ると“母”に関するもの は、“母性之は’ “母とは何か’ “母性”概 念と母性看護の考え方”などで、“母と子” については、“周産期における母と子’ ‘新 生児と母子結合”などであった。15のキーワ 一ドの中で、「母性観」「母親になる過程」

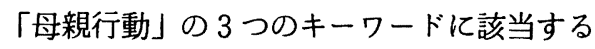
あのはみられなかった。

2. 経年的推移について (図 3 )

解説 122 文献は、1935 年当初から88年ま で、53年間にわたり発表されていた。既に報 告してきた、研究・抄録が 1962 年に最初の 発表をみたのに比べると、解説は先行すると と27年、現在に至るまで長きにわたっていた。 母性性に関する文献全体からみた各年毎の発 表数は、1987年が最も多かったのに対し、 解説では 6 年早い1981年にピークを迎えて いる。

3. キーワード別経年的推移について(図 4)

1935 年の最初にみられた文献は「母性愛」 で、1981年までの46年間に及んで発表され、 しかむ最初の 1935 年から63年までの間は、 「母性愛」のみが占めていた。

次に、「母子関係」についてみると「母性 愛」の発表から遅れること35年の1970年に 初めて記述がみられ、1978、79年と続いた。 しかし、その後の文献数は減少した。それに かわって「母子相互作用」が1979年に台頭 し、その後 $81 、 83 、 84$ 年と継続して増加し ていった。しかし、85年以降は、減少してい る。

\section{4. 母性性に関する解釈の動向}

1930～60年代までの「母性愛」などに表 現される母性は、“本能的なもの”や、“天 性”“生れながらにして持っているもの”な どとしている。また、母性愛は“惜しみなく 与える愛でなりればならない”や、母とは “その一切をささげつくして日本国民として のみ生きている子の母である”としていた。 また、母親となる婦人は家のため、夫のため 人生のために、心身の健康を心掛けるという ように言われ・ねばならない’ ‘てうあるべ き’と表現されていた。しかし、1970年代 に入り、母性之は本当に本能なのであろうか という疑問が持たれ始める。さらに1980年 代に入ってからは、はっきりと本能ではなく 後天的な環境や経験に影響されるものとして 表現されるまでに変化してきた。

「母子関係」という言葉については、1950 ～60年頃には母から子供へと一方向的なもの であった。しかし、1970年代後半から80年 代に入り、「母子関係」というものは母加 子、子から母へというように互いに関係しあ うものとされ、それを「母子相互作用」と表 現するに至る变遷が明らかになった。

\section{III 考察}

今まで分析してきた母性性に関する422文 献の傾向は、1980年後半に激増を示してい たが、解説では1978年から80年代全体にわ たって文献がみられていた。また、研究・抄 録文献と比較して、早期より長期間にわたり 発表されていたととを考えあわせると、母性 性に関する内容が、研究・抄録より先行して 解説で取り上げ論じられているととがわかっ た。さらに、その文献の標題が「母性愛」で あったととから、「母性愛」という言葉が、 1935 年より使われ、しかも1963年までの 27年間は、一つの表現のみが用いられていた ことが明らかにされた。その後は、解説が急 

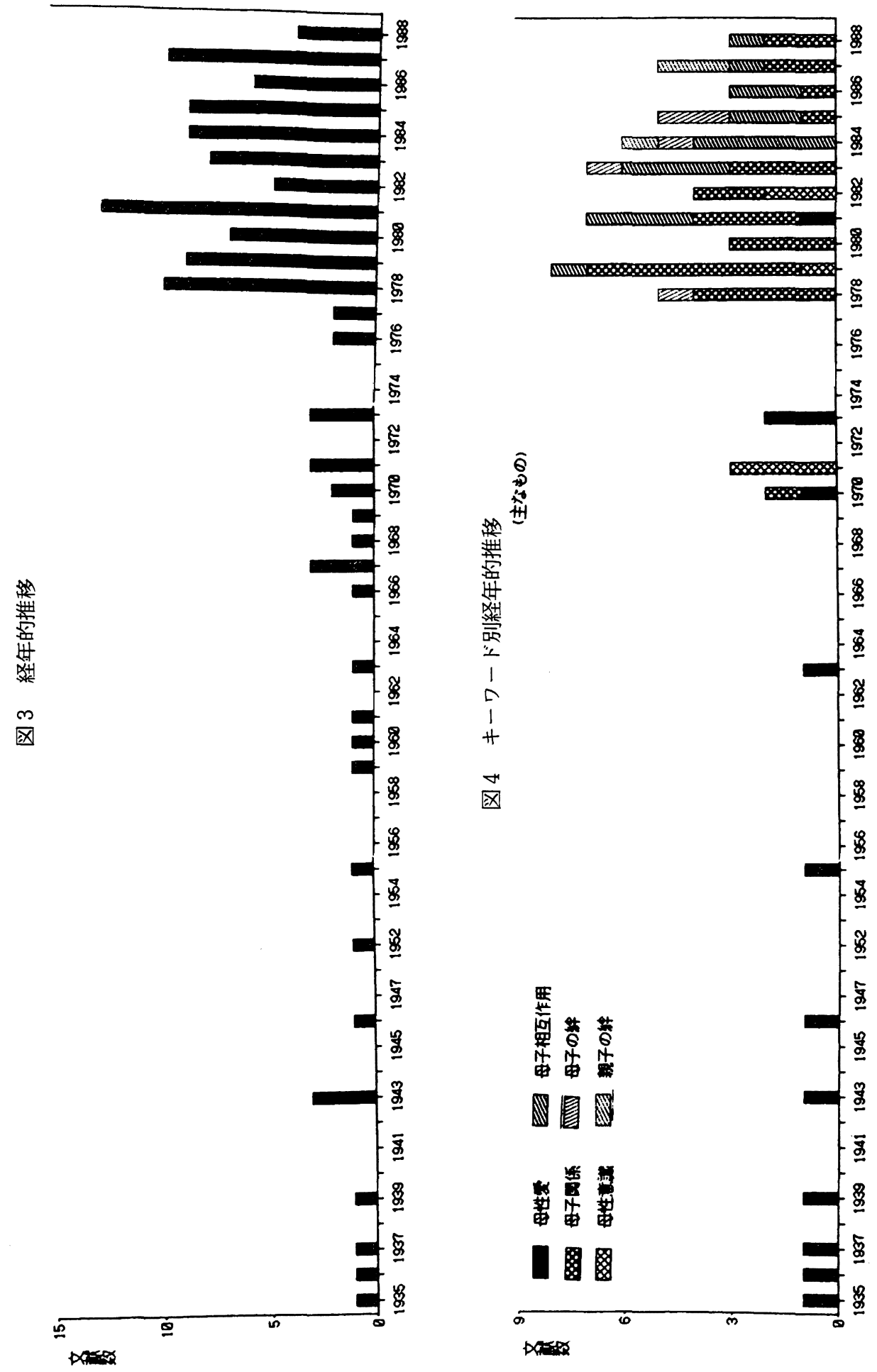
増した1978年より「母子関係」をはじめ様 々に表現されるようになり、既報のように解 説でも同様の傾向であった。てのととを裏付 ける著書“愛育”（1935年創刊）によれば、 「母性愛」「母子関係」「母子相互作用」へ と変遷の過程をみるととができる。

母性は長い間本能であるとする考えが続い ていたが、後天性のものであるとしたてと、 母と子は相互作用しあっているととなどが 解明され、80年代の母性については樣々な考 えや捉え方にまで広がり、まだそれが模索状 態であるてとが浮彫りになった。同時にまた、 母性性に関する解釈の曖昧さすより明確とな った。

てれらをあとに、今後さらに母性性の概念 の追及を継続していきたいと考える。 